\title{
РАСТЕНИЕВОДСТВО
}

\section{EFFECT OF BETA-AMINOBUTYRIC ACID ON ACTIVITY OF PEROXIDASE AND POLYPHENOL OXIDASE ENZYMES IN CUCUMBER INFECTED WITH NEMATODE MELOIDOGYNE JAVANICA}

\author{
NiloufarMahmoudi \\ Peoples' Friendship University of Russia (RUDN University) \\ 6 Miklukho-Maklaya Street, Moscow, 117198, Russian Federation \\ niloofarmahmoodi@ymail.com
}

\begin{abstract}
Beta-amino-butyric acid is introduced as an inducer of resistance in plants against plant pathogens. In this research, the induction of some defensive compounds including peroxidase and polyphenol oxidase enzymes by this compound against the rootstock node-producing nematode Meloidogyne javanica in cucumber was investigated. The results showed that inoculation of cucumber roots infected with rootknot nematode with the chemical composition of BABA from the first day after inoculation increased the activity of peroxidase enzyme and reached its maximum on the fourth day of this activity. Induction of the activity of polyphenol oxidase enzyme showed a gradual increase with a significant difference in comparison to the control and healthy plants and reached the maximum on the fourth day. The electrophoresis of peroxidase isozymes showed that isozyme peroxidase forms in cucumber roots induced by $\mathrm{BABA}$ were much more potent than pathogen-induced isozymes. In plants treated with nematode plus $\mathrm{BABA}$, two isozymes were $\mathrm{Rf}=00.31$ and $\mathrm{Rf}=34 / 0$, which were stronger than control (inoculated with nematode).
\end{abstract}

Key words: induction of resistance, nematode generating root node, beta-amino-butyric acid, peroxidase, polyphenol oxidase

\section{INTRODUCTION}

Nematodes generating root nodes (Meloidogyne spp.) are among the forced parasites and most important group of nematodes of plant parasite throughout the world [1-3]. These nematodes have a worldwide spread and have a very complicated mutual relationship with host compared to the other plant pathogens [4]. Various nematode killers including Chloropicrin, ethylene dibromide, D-D compound (1,3-Dichloropropene; 1,2-Dichloropropane) and methyl bromide have been introduced to control these nematodes. But in addition to much costs of using these chemical substances, various environmental dangers and problems have limited or prohibited use of them [5]. Induction resistance is considered to be a biological protection method aiming to activate the defensive system of plant and consequently limiting the pathogen's activity. The created resistance is not dedicated, is effective on a wide spectrum of pathogens, and varies 
with antagonism in that active reaction of plant intervenes in this resistance. Also it is distinguished from chemical methods given that inducing agents are not poisonous for the pathogen $[3,6]$. A group of agents such as pathogens (fungi, bacteria, viruses, and nematodes) that induce the over-sensitivity phenomenon, strains with weak pathogenicity or non-pathogenic, stimulants with pathogenic origin (Chitin, Glucan, proteins, fats), not live stimulants including synthetic chemical compounds like 2,6-dichloroisonicotinic acid (INA), beta-aminobutyric acid (BABA), benzo-(1,2,3)-thiadiazole7-carbothioic acid s-methyl ester (BTH), salicylic acid, mineral salts, potassium phosphate and compounds with live organisms origins induce resistance in plants $[7,8]$. The chemical composition of BABA is a synthetic non-protein amino acid that in many species of plants induces resistance against fungi pathogens, bacteria, viruses and nematodes [9, 10]. Oort and colleague (1960), for the first time, showed the induced resistance in tomato against late burning disease in the plants treated by BABA [11, 12]. BABA through stimulating a plant to make physical barriers, accumulation of proteins related to pathogenicity (PR-Proteins), phytotoxins, over-sensitivity reaction and rapid production of active oxygen are effective in stimulating defensive mechanisms of the plant against diseases.Different stimulators through a similar signaling route stimulate defensive system of the plant. BABA also acts in different signaling routes including salicylic acid, jasmonic acid, and ethylene. However, the complete mechanism of BABA action on resistance induction is not exactly known [13]. Ben Rejeb (2018) showed that BABA resistance in the mutants of Arabidopsis plant in which routes of salicylic acid, jasmonic acid and ethylene were damaged [14]. Therefore, in addition to the mentioned routes, it is possible that there are also other signaling routes for BABA. Plants always resist against the plant pathogenic agents and pests through a wide range of defensive compositions. Peroxidase and polyphenol-oxidase are among the enzymes related to plant defense against a wide range of plant pathogenic agents. These enzymes are oxidative and are involved in production and use of active oxygen, formation of lignin and other oxidized phenols as defensive barriers for strength of cell construction [15, 16]. Kim and colleagues showed that PR-1 is accumulated in the tobacco plants treated with BABA. Powell and Hodge (2018) reported that in the Arabidopsis plants, applying BABA in leafsprayed form even in low concentrations resulted in accumulation of proteins' PR (PR-5, PR-2_PR-1) [17, 18]. The chemical composition of BABA creates a systemic resistance against peanut leaf spot disease (Cercosporidium personatum). Devran and Baysal (2018) showed that in the greenhouse conditions, BABA only is an inducer such that reduces this disease significantly [19]. Applying DL-2-Aminobutyric acid in soil has reduced the number of created scabies by Nocobbus serendipiticus without damage to tomato plants $[12,20]$. Oka et al. (1999) demonstrated inducing resistance in tomato against nematode generating root node using BABA, through showing its effect on reduction of disease (evaluating number of scabies, number of nematode eggs and wet weight of root and stem) [20]. Given the notable results of using BABA against nematode generating root node by Oka et al. in 1999 [20], the impact of beta-aminobutyric acid as a stimulant of the defensive system of plant to induce resistance in cucumber against nematode generating root node was the objective of this research. In this investigation, also the possibility of induction and the rate of activity defensive enzymes of peroxidase and polyphenol oxidase have been evaluated. 


\section{MATERIALS AND METHODS}

\section{Preparing $M$. javanica nematode population}

After providing a plant sample infected to nematode, using Single egg mass method and reproducing it consecutively on the roots of tomato seedlings of type Rutgers, its purification and reproduction were performed. In most of the nematology investigation, the egg and larvae of two nematodes are used in order to create an infection. However, generally, because some eggs are not alive, using the second larvae of nematode is more common. Extracting egg and providing second larvae was done using Hussey (1973) method [21].

\section{Preparing stimulant of beta-aminobutyric acid}

Chemical substance of beta-aminobutyric acid (BABA) was supplied from Sigma Company and its $20 \mathrm{mM}$ concentration was used for experiments [20].

Investigating the activity of peroxidase and polyphenol oxidase enzymes in cucumber infected with the Nematode generating root node by inoculated with BABA

Disinfected cucumber seeds were planted in pots of $130 \mathrm{~cm}^{3}$ containing sterilized soil (including sand, leafy soil, farm soil with the ratio of $1: 1: 1$ ). In the $4-6$ leafy stages, the seedlings of cucumber were treated by the method of soaking soil-drench by $20 \mathrm{mM}$ solution of beta-aminobutyric acid. $10 \mathrm{ml}$ of the mentioned solution was added to each seedling [20]. One day after the treatment of cucumber seedlings with aminobutyric acid, the population of 2000 second larvae was inoculated for any plant. In order to hold constant the temperature around the plant root, pots were put in a big bath of water. The temperature of the water inside the bath was $27^{\circ} \mathrm{C}$ and the environment temperature was set $27 \pm 2{ }^{\circ} \mathrm{C}$.

In this experiment inoculation of cucumber seedlings with only nematode (evidence), only BABA, nematode plus BABA and distilled sterile water as experiment treatments were considered. In the evidence plants instead of BABA, the distilled sterile water was used. After inoculation of seedling with nematode, a sampling of the plants' root was done in days, 1, 3, 4, 5 and 7 after inoculation of plants with nematode. This experiment was conducted with three iterations in the form of factorial experiment based on a completely random plan.

\section{Extracting protein from plant tissue}

An amount of $0.5 \mathrm{~g}$ of the plant root tissue was grinded well in a Chinese mortar that was cooled previously in the refrigerator using liquid nitrogen. Then $1 \mathrm{ml}$ of a sample buffer of phosphate sodium ( $\mathrm{pH}$ 6) was added to it and fully homogenized. During the whole work time, the mortar was in a bath full of ice. The resulting compound immediately was transferred to $1.5 \mathrm{ml}$ micro-tubes and was centrifuged $13000 \mathrm{rpm}$ for $20 \mathrm{minu}-$ tes at $4{ }^{\circ} \mathrm{C}$ (inside the refrigerator). The surface extract was separated to do experiments and was kept in $-40{ }^{\circ} \mathrm{C}$ before performing an experiment [22].

\section{Evaluation of the total soluble protein in the extract}

Evaluation of the total soluble protein in the extract including providing standard curve using standard protein (bovine serum albumin, fraction 5) according to [23]. For the end, $20 \mu \mathrm{l}$ of the extract of each sample was blended with $3 \mathrm{ml}$ of Bradford reagent 
in a little test tube then the amount of light absorption was read in wavelength $\max =595$ using the spectrophotometer. For each sample, three iterations were considered. The total amount of protein of each extraction was calculated using a standard curve.

Evaluation of the rate of peroxidase enzyme activity was made by [24] method. $2 \mathrm{ml}$ of reaction mixture including some of the extract containing $40 \mathrm{mg}$ protein, 20 micro-liters Guicoll and a sufficient amount of buffer $25 \mathrm{mM}$ phosphate citrate $(5.4 \mathrm{pH})$, such that the final measure is $2 \mathrm{ml}$, was blended in a test tube and spectrophotometer device was zeroed using this compound in wavelength $\lambda_{\max }=475 \mathrm{~nm}$. Then $10 \mu 1$ of peroxidase hydrogen $30 \%$ was added to the mixture and was blended rapidly and changes of light absorption by 10-second intervals and for 1 minute was measured. The activity of enzyme was calculated in the form of changes of light absorption in a minute in $\mathrm{mg}$ protein.

\section{Evaluating the rate of polyphenol oxidase enzyme activity}

$2 \mathrm{ml}$ of the reaction compound including some of the extract sample containing $40 \mathrm{mg}$ protein, $20 \mu \mathrm{l}$ of proline solution and a sufficient amount of buffer of $25 \mathrm{mM}$ phosphate citrate ( $\mathrm{pH}$ 6.4) was blended completely in a little test tube, such that the final measure is $2 \mathrm{ml}$, and this mixture was aerated for 2 minutes by vortex. Then spectrometer device using this compound was zeroed in wavelength $\max =515 \mathrm{~nm}$. Then $40 \mu \mathrm{l}$ of $100 \mathrm{mM}$ Pyrocatechol solution was added to above compound and rapidly was blended and immediately the changes of light absorption was measured by 10 -second intervals for 1 minute. The activity of the enzyme was calculated according to the changes of light absorption per minute in every $\mathrm{mg}$ of protein [24].

\section{Indigenous electrophoresis (Native-PAGE) of peroxidase Isozymes}

Indigenous electrophoresis using separator gel $12 \%$ and compactor $6 \%$ was conducted. In each well, some extract containing $30 \mu \mathrm{g}$ protein was poured and the final volume of each well was reached to $35 \mu \mathrm{l}$ using the sample buffer. Voltage in the compacting gel stage $75 \mathrm{~V}$ and in the separator gel stage $100 \mathrm{~V}$ was considered. Then the gel run through the glass plates exited and several times was washed by stilled water. Then in the buffer citrate-phosphate, $25 \mathrm{mM}$ containing Glycol with the final concentration of $5 \mathrm{mM}$ and $\mathrm{pH} 5.4$ was put for 30 minutes on the shaker. Then 1 percent of hydrogen peroxidase was added to it drop by drop. After some moments brown bands showing peroxidase isozymes appeared [25].

\section{RESULTS}

\section{Evaluating the rate of peroxidase enzyme activity}

As it is observed in figure 1 in the two treatment of inoculation of seedlings with BABA only and with BABA plus nematode, the enzyme activity rate in day 1 and 3 had no significant difference with evidence (inoculated only with nematode), but since day 4 these two treatments had a significant difference with evidence. In the plants related to these two treatments and evidence, the maximum activity of the enzyme was observed in day 4 after inoculation with the nematode. The healthy plant treatment in day 1 , 5 and 7 had no significant difference with evidence but in day, 3 and 4 had a sign with 
evidence. In addition, the activity of peroxidase enzyme in the treatment of cucumber inoculated with BABA plus nematode in consecutive days increased with a significant difference compared to each other but there was a significant difference in days 5 and 7 of this treatment.

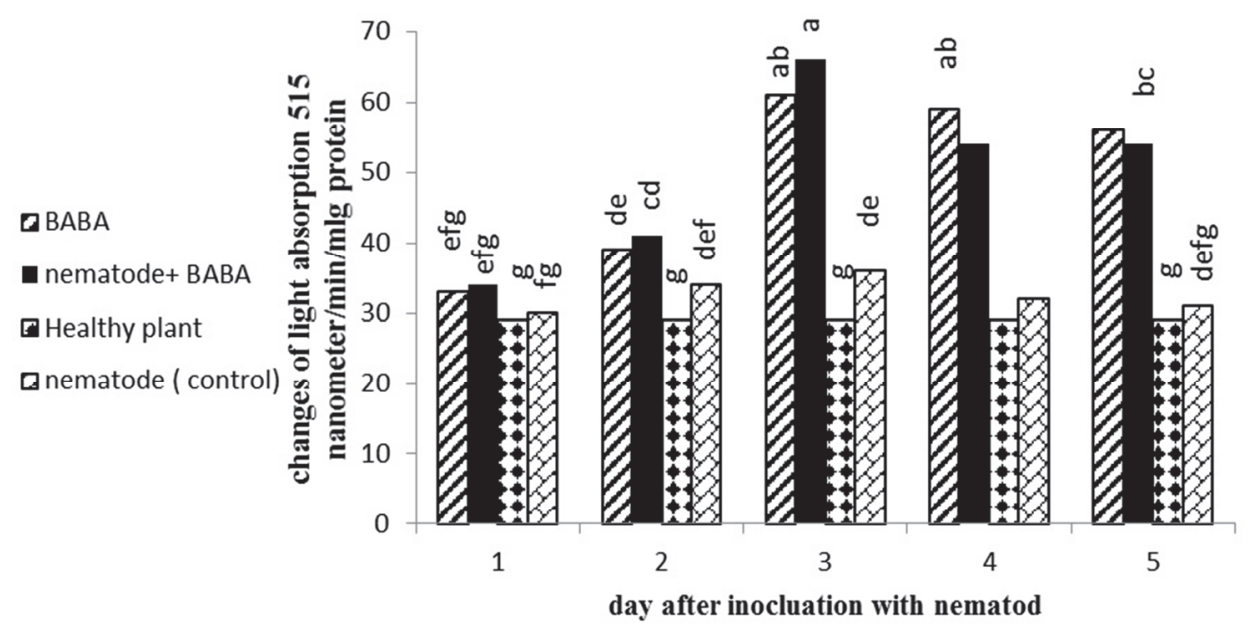

Figure 1. The effect of beta aminobutyric acid (BABA) on the activity

of peroxidase enzyme in the root of cucumber infected with nematode generating root node.

The numbers of this table are average of three iterations. Numbers having same letters, according to

Danken's test has not a significant difference in level $5 \%$. The activity of peroxidase enzyme has

been shown in the form of changes light absorption in $475 \mathrm{~nm}$ per minute per mg protein

\section{Evaluating the rate of activity of polyphenol oxidase enzyme}

Two treatments of seedlings with BABA plus nematode and BABA only and treatment of healthy plant in day 1 with evidence (inoculated with nematode) had no significant difference but in days, 3 and 4 had a significant difference with evidence. The activity of the enzyme in treatment with BABA plus nematode in day 3 and 4 had no significant difference with each other and the maximum activity of the enzyme was in day 4 (figure 2).

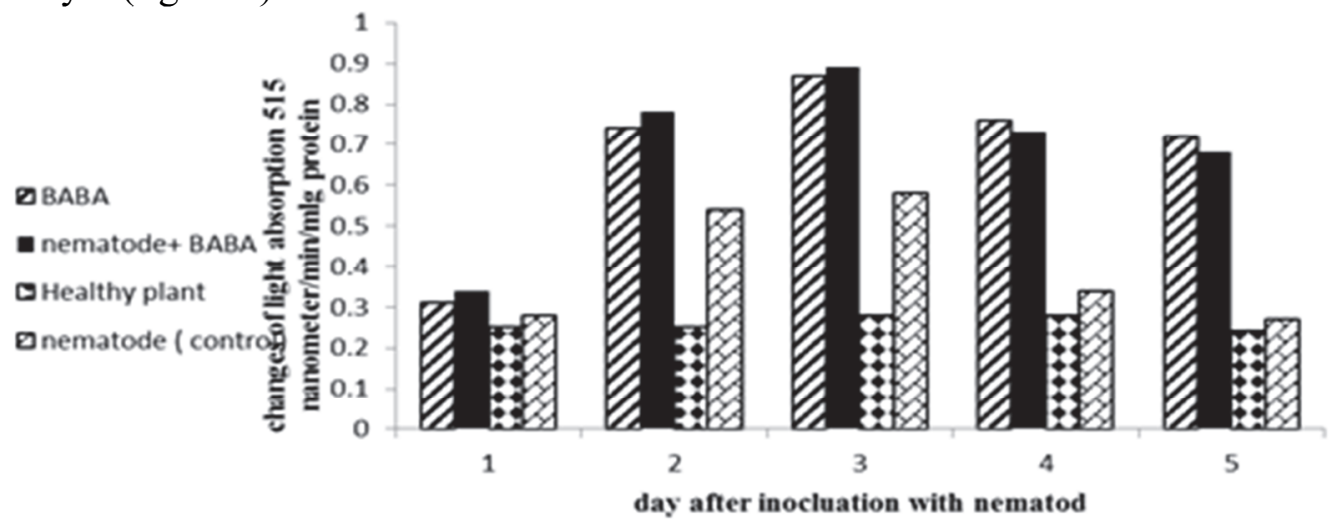

Figure 2. The effect of beta-aminobutyric acid (BABA) on the activity of polyphenol peroxidase enzyme in the seedlings of cucumber infected with nematode generating root node.

The numbers of this table are average of three iterations. Numbers having same letters, according to Danken's test hasn't a significant difference in level $5 \%$. The activity of polyphenol peroxidase enzyme has been shown in the form of changes light absorption in $515 \mathrm{~nm}$ per minute per $\mathrm{mg}$ protein 


\section{Electrophoresis of peroxidase isozyme}

As it is observed in figure 3 , the bands of peroxidase isozymes are in red to brown color with a relative movement of $\mathrm{R}_{\mathrm{f}}=0.31$ and $\mathrm{R}_{\mathrm{f}}=0.34$.

A: bands of peroxidase isozyme are related to treating cucumbers inoculated with nematode plus BABA. In this treatment, two isozymes with $R_{f}=0.34$ and $R_{f}=0.31$ has been expressed that compared to the evidence (inoculated with nematode only) of healthy the plant (D) the bands have been expressed stronger. Isozymes with $R_{f}=0.34$ I the healthy plant compared to this treatment was weaker in terms of density.

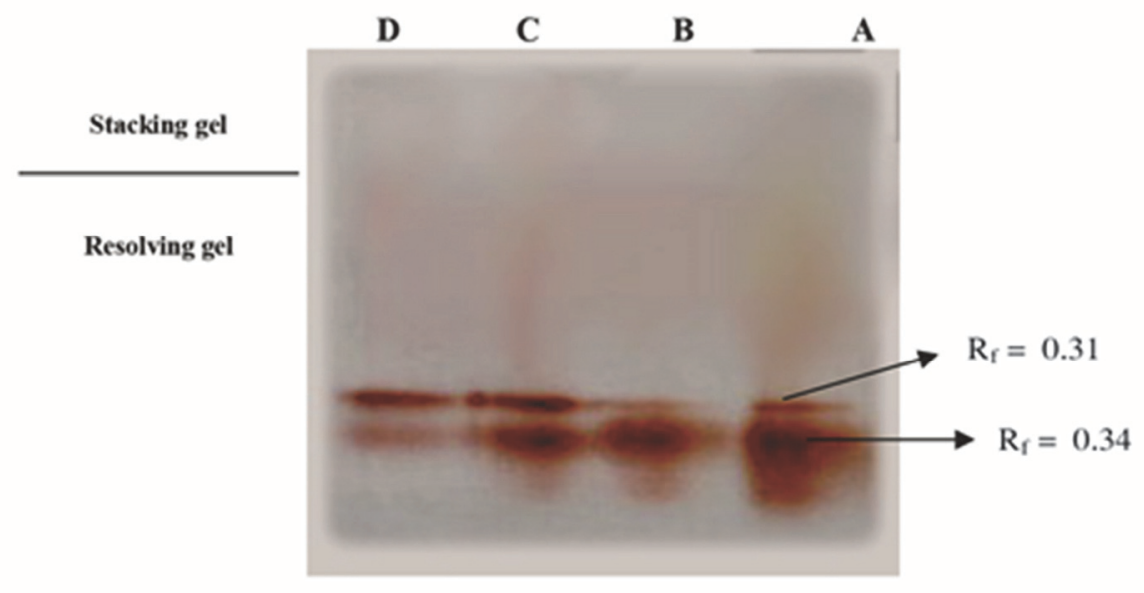

Figure 3. Indigenous electrophoresis of the peroxidase enzyme in the seedlings of cucumber infected with nematode generating root node inoculated with BABA and comparing it with a healthy plant respectively:

A: nematode plus BABA, B: BABA, C: nematode, D: healthy plant

$\mathrm{B}$ : bands of isozymes peroxidase is related to the treatment of seedlings of cucumber inoculated wit BABA in which two isozymes with $R_{f}=0.34$ and $R_{f}=00.31$ have been expressed that compared to a healthy plant, isozyme with $\mathrm{R}_{\mathrm{f}}=0.34$ is very weak in the healthy plant while in this treatment was observed with a notable density. Then it can be concluded that this isozyme is more important in the defensive mechanisms of the plant.

$\mathrm{C}$ : bands of isozymes is related to the treatment of cucumber seedlings inoculated with nematode (evidence) that compared to the treatment of nematode plus BABA, isozymes are weaker in density.

$\mathrm{D}$ : isozymic bands are related to the healthy plant. In this treatment, two isozymes with $\mathrm{R}_{\mathrm{f}}=0.31$ and $\mathrm{R}_{\mathrm{f}}=0.34$ have been expressed very weakly.

\section{DISCUSSION}

In plants confronted with microorganisms and development of mechanic damages, important physiologic changes are induced and generally, enzymes and defensive compositions of the plant are activated. Inducing resistance by increase and synthesis of the set of chemical substances occurs during a set of complicated reaction in the host 
plant and cause stimulation of defensive system of the plant. Many substances have protein nature including defensive enzymes of peroxidase in the ligninization process, production of suberin and tannin (physical and chemical barriers) that intervene in the permeability the plant tissue against nematode generating root node. Despite important developments, regarding different stimulants and the defensive responses of plants are available but there is little information about the induced enzymes by BABA. In the recent study from the three isomer aminobutyric acid $(\alpha, \beta, \gamma)$, the isomer $\beta$ was used. It has been found that BABA moves in plants systematically and explains some of the systemic protection that is created by BABA against plant diseases. In addition, induction of signal transmitters including salicylic acid and jasmonic acid also complement the systemic induction in the plant [16]. In this research, the induction resistance markers like peroxidase (POX) and polyphenol peroxidase (PPO) were used for examination. Peroxidase enzyme as a systemic induced and a marker is necessary for resistance induction in the plant to create cross-link and strengthening cell wall [26]. This enzyme by intervention in the final stage of lignin production increases the resistance against disease [18]. That for the end, the peroxidase of cell wall needs $\mathrm{H}_{2} \mathrm{O}_{2}$ and monolignal radicals [27]. The activity of peroxidase enzyme in the cucumber was measured by four different treatments including only nematode, BABA plus nematode, BABA only and healthy evidence. From the results of the examining the activity of peroxidase enzyme, it is inferred that BABA in the experiment has increased the activity of peroxidase enzyme. The activity of peroxidase enzyme began from day 1 after nematode inoculation and in day 4 reached its maximum activity, and then in the next days reduced gradually. The reduction that was taken place in the evidence harshly and in the other treatments very slowly is a reason for the sustainability of resistance induction effect by BABA. Similar to these results, the increase of peroxidase enzyme in the roots of cucumber treated by P.corrugata bacteria was observed against Pythium aphanidermatum fungi $[28,29]$. Vasanthi et al. (2017) showed that treating rice by Pseudomonas fluorescens bacteria resulted in induction of systemic resistance against Rhizoctonia solani and the result of this resistance was increase of activity of kitinase and peroxidase enzymes activity. Castagnone-Sereno (2012) reported that peroxidase enzyme is involved in the resistance to nematode Meloidogyne spp. [30]. Also it was found that changes of activity of the peroxidase enzyme showed the biochemical changes of plant and some of resistance reactions [22, 31]. Reuveni and Bothma (1985) showed that increase of resistance of tomato plants inoculated with acibenzolar-S-methyl against bacterial canker of Clavibacter michiganensis ssp. [22]. C. michiganensis is associated with significant increase of activity of peroxidase and kitinase enzyme. In this study, also the activity of polyphenol oxidase enzyme in the cucumber was measured by the mentioned treatments. BABA resulted in an increase of activity of this enzyme compared to healthy plant and its activity had a significant difference with evidence (inoculated only with nematode). Therefore, BABA causes significant increase of activity of polyphenol oxidase in the roots of cucumber against nematode $M$. javanica. Reuveni showed that polyphenol oxidase enzyme in the roots of tomato increases at the temperature of $30{ }^{\circ} \mathrm{C}$ against nematode generating root node [22]. Also, it has been found that polyphenol oxidase in tomato plants is expressed very much and it is accompanied 
with an increase of resistance to pathogens [32]. Shikano et al. (2018) identified in the roots of tomato infected with nematode generating root node Meloidogyne spp. genes in the defensive mechanisms of the plant that induces enzymes like polyphenol oxidase, catalase, lipoxygenase and peroxidase. The role of polyphenol oxidase in producing resistance in the Penisetum glaucum plant against Sclerospora graminicola was also demonstrated by $[33,34]$. Considering the results obtained from changes of activity of the two-peroxidase and polyphenol oxidase enzymes in this experiment it can be said that nematode after reaching root and penetrating inside the root tissue, naturally hurts the root and through a lot of intercellular movement in the root tissue reaches the nutrition place. This penetration and movement of pathogen due to that is intercellular and does not destroy cells along its way results in the induction of defensive metabolites in a very little amount. By the introduction of nematodes into plant, some secretions are produced by the nematode that influences the biochemical reactions and accompanies with stopping some of the biochemical reactions and naturally reduction of synthesis of compositions and defensive enzymes [12]. Therefore, in the treatment with nematode, only the amount of induction of defensive enzymes of POX and PPO compared to the treatments inoculated with BABA is fewer significantly, while BABA causes the increase of induction and synthesis of peroxidase and polyphenol oxidase greatly. More research is needed about the effect of BABA on the other plants hosting nematode generating root node and other species of nematode on the mechanisms of action of BABA in producing resistance to nematode generating root node in cucumber.

\section{CONCLUSIONS}

The results showed that inoculation of roots of infected cucumber with root-knot nematode with the chemical composition of BABA from the first day after inoculation with nematode increased the activity of peroxidase enzyme and reached its maximum on the fourth day of this activity. Induction of the activity of polyphenol oxidase enzyme showed a gradual increase with a significant difference in comparison to the control and healthy plants and reached the maximum on the fourth day. The electrophoresis of peroxidase isozymes showed that isozyme peroxidase forms in cucumber roots induced by BABA were much more potent than pathogen-induced isozymes. In plants treated with nematode plus BABA, two isozymes were $R_{f}=00.31$ and $R_{f}=34 / 0$, which were stronger than control (inoculated with nematode).

\section{ACKNOWLEDGMENTS}

Ministry of Education and Science of the Russian Federation on the program to improve the competitiveness of RUDN University among the world's leading research and education centers during 2016-2020 financially supported this research.

(C) NiloufarMahmoudi, 2019.

\section{REFERENCES}

[1] Triki E., Trabelsi I., Amri M., Nefzi F., Kharrat M., Abbes Z. Effect of benzothiadiazole and salicylic acid resistance inducers on Orobanche foetida infestation in Vicia faba. Tunisian Journal of Plant Protection. 2018; 13(1):113-125. 
[2] Zhong Y., Wang B., Yan J., Cheng L., Yao L., Xiao L., Wu T. DL- $\beta$-aminobutyric acid-induced resistance in soybean against Aphis glycines Matsumura (Hemiptera: Aphididae). PloS one. 2014; 9(1):e85142. Available from: doi: 10.1371/journal.pone.0085142.

[3] Gao J., Bi W., Li H., Wu J., Yu X., Liu D., Wang X. WRKY transcription factors associated with NPR1-mediated acquired resistance in barley are potential resources to improve wheat resistance to Puccinia triticina. Frontiers in plant science. 2018; (9):1486. Available from: doi: 10.3389/fpls.2018.01486.

[4] Abad P., Favery B., Rosso M.N., Castagnone-Sereno P. Root-knot nematode parasitism and host response: molecular basis of a sophisticated interaction. Molecular plant pathology. 2003; 4(4):217-224. Available from: doi: 10.1046/j.1364-3703.2003.00170.x.

[5] Nguyen C.N., Perfus-Barbeoch L., Quentin M., Zhao J., Magliano M., Marteu N., Da Rocha M., Nottet N., Abad P., Favery B. A root-knot nematode small glycine and cysteine-rich secreted effector, MiSGCR1, is involved in plant parasitism. New Phytologist. 2018; 217(2):687—699. Available from: doi: 10.1111/nph.14837.

[6] Görlach J., Volrath S., Knauf-Beiter G., Hengy G., Beckhove U., Kogel K.H., Oostendorp M., Staub T., Ward E., Kessmann H., Ryals J. Benzothiadiazole, a novel class of inducers of systemic acquired resistance, activates gene expression and disease resistance in wheat. The Plant Cell. 1996; 8(4):629 - 643. Available from: doi: 10.1105/tpc.8.4.629.

[7] Wagner A., Norris S., Chatterjee P., Morris P.F., Wildschutte H. Aquatic Pseudomonads inhibit oomycete plant pathogens of glycine max. Frontiers in microbiology. 2018; (9):1007. Available from: doi: 10.3389/fmicb.2018.01007.

[8] Singh S., Singh A., Kumar S., Mittal P., Singh I.K. Protease inhibitors: recent advancement in its usage as a potential biocontrol agent for insect pest management. Insect science. 2018. Available from: doi: 10.1111/1744-7917.12641.

[9] Starý T., Satková P., Piterková J., Mieslerová B., Luhová L., Mikulík J., Kašparovský T., Petrrivalský M., Lochman J. The elicitin $\beta$-cryptogein's activity in tomato is mediated by jasmonic acid and ethylene signalling pathways independently of elicitin — sterol interactions. Planta. 2018. 1-11. Available from: doi: 10.1007/s00425-018-3036-1.

[10] Alshammari G.M., Balakrishnan A., Chinnasamy T. Protective role of germinated mung bean against progression of non-alcoholic steatohepatitis in rats: A dietary therapy to improve fatty liver health. Journal of Food Biochemistry. 2018; 42(5):e12542. Available from: doi: $10.1111 / \mathrm{jfbc} .12542$.

[11] Oort A.J.P., Van Andel O.M. Aspects in chemotherapy. Mededel. Opz. Gent. 1960; 25:961—992.

[12] Prasad S., Webster J.M. The effect of amino acid antimetabolites on four nematode species and their host plants. Nematologica. 1967; 13(2):318-320.

[13] Cohen Y.R. $\beta$-aminobutyric acid-induced resistance against plant pathogens. Plant disease. 2002; 86(5):448 - 457. Available from: doi: 10.1094/PDIS.2002.86.5.448.

[14] Ben Rejeb I. BABA in priming tomato for enhanced tolerance to drought, salinity and fungal stress and combinations thereof. [Dissertation] Neuchâtel; 2018.

[15] Singh S.K., Sung T.Y., Chung T.Y., Lin S.Y., Lin S.C., Liao J.C., Hsieh W.Y., Hsieh M.-H. ACR11 modulates levels of reactive oxygen species and salicylic acid-associated defense response in Arabidopsis. Scientific reports. 2018; 8(1):11851. Available from: doi: 10.1038/s41598-01830304-0.

[16] Wilkinson S., Pastor V., Paplauskas S., Pétriacq P., Luna E. Long-lasting $\beta$-aminobutyric acidinduced resistance protects tomato fruit against Botrytis cinerea. Plant Pathology. 2018; 67(1):30 - 41. Available from: doi: 10.1111/ppa.1272517.

[17] Powell G., Hodge S. Effects of $\beta$-aminobutyric acid on aphid stylet activities. IOBC-WPRS Bulletin. 2018; 135:124-126.

[18] Li K., Wu G., Li M., Ma M., Du J., Sun M., Sun X., Qing L. Transcriptome analysis of Nicotiana benthamiana infected by Tobacco curly shoot virus. Virology journal. 2018; 15(1):138. Available from: doi: 10.1186/s12985-018-1044-1. 
[19] Devran Z., Baysal Ö. Induction of resistance to Meloidogyne incognita by DL-beta amino butyric acid under salt stress condition. Australasian Plant Disease Notes. 2018; 13(1):20. Available from: doi: 10.1007/s13314-018-0304-7.

[20] Oka Y., Cohen Y., Spiegel Y. Local and systemic induced resistance to the root-knot nematode in tomato by DL- $\beta$-amino-n-butyric acid. Phytopathology. 1999; 89(12):1138-1143. Available from: doi: 10.1094/PHYTO.1999.89.12.1138.

[21] Hussey R.S. A comparison of methods of collecting inocula of Meloidogyne spp., including a new technique. Plant Dis. Rep. 1973; 57:1025-1028.

[22] Reuveni R., Bothma G.S. The relationship between peroxidase activity and resistance to Sphaerotheca fuliginea in melons. Journal of Phytopathology. 1985; 114(3):260-267. Available from: doi: 10.1111/j.1439-0434.1985.tb00851.x.

[23] Bradford M.M. A rapid and sensitive method for the quantitation of microgram quantities of protein utilizing the principle of protein-dye binding. Analytical Biochemistry. 1976; 72 $(1-2): 248-254$.

[24] Diniz I., Azinheira H., Figueiredo A., Gichuru E., Oliveira H., Guerra-Guimarães L., Silva M.C. Fungal penetration associated with recognition, signaling and defence-related genes and peroxidase activity during the resistance response of coffee to Colletotrichum kahawae. Physiological and Molecular Plant Pathology. 2018. Available from: doi: 10.1016/j.pmpp.2017.12.005.

[25] Porat R., Vinokur V., Weiss B., Cohen L., Daus A., Goldschmidt E.E., Droby S. Induction of resistance to Penicillium digitatum in grapefruit by $\beta$-aminobutyric acid. European Journal of Plant Pathology. 2003; 109(9):901-907. Available from: doi: 10.1023/B:EJPP.0000003624.28975.45.

[26] Sabbagh E., Sabbagh S.K., Panjehkeh N., Bolok-Yazdi H.R. Jasmonic acid induced systemic resistance in infected cucumber by Pythium aphanidermatum. Tarim Bilimleri Dergisi-Journal of Agricultural Sciences. 2018; 24(1):143-152.

[27] Hossain M.A., Li Z.G., Hoque T.S., Burritt D.J., Fujita M., Munné-Bosch S. Heat or cold priming-induced cross-tolerance to abiotic stresses in plants: key regulators and possible mechanisms. Protoplasma. 2018; 255(1):399 - 412. Available from: doi: 10.1007/s00709-017-1150-8.

[28] Dorjey S., Dolkar D., Sharma R. Plant growth promoting rhizobacteria Pseudomonas: a review. Int J Curr Microbiol App Sci. 2017; 6(7):1335-1344. Available from: doi: 10.20546/ijcmas. 2017.607.160.

[29] Vasanthi V., Samiyappan R., Vetrivel T. Development of a new chitin based bio-formulation of Pseudomonas fluorescens and a natural insecticide (Vitex trifolia) against Indian Tomato Leaf Curl Virus (iTLCV) and its whitefly vector. The Pharma Innovation Journal. 2017; 6(11): 574-578.

[30] Castagnone-Sereno P. Meloidogyne enterolobii (= M. mayaguensis): profile of an emerging, highly pathogenic, root-knot nematode species. Nematology. 2012; 14(2):133-138. Available from: doi: 10.1163/156854111X601650.

[31] Nuñez A.M., Rodríguez G.A., Monteiro F.P., Faria A.F., Silva J.C., Monteiro A.C., Carvalho C.V., Gomes L.A., Souza R.M., de Souza J.T., Medeiros F.H. Bio-based products control black rot (Xanthomonas campestris pv. campestris) and increase the nutraceutical and antioxidant components in kale. Scientific Reports. 2018; 8(1):10199. Available from: doi: 10.1038/s41598018-28086-6.

[32] Zheng Y., Wang X., Liu S., Zhang K., Cai Z., Chen X., Zhang Y., Liu J., Wang A. The endochitinase of Clonostachys rosea expression in Bacillus amyloliquefaciens enhances the Botrytis cinerea resistance of tomato. International Journal of Molecular Sciences. 2018; 19(8):2221. Available from: doi: 10.3390/ijms19082221.

[33] Shikano I., Pan Q., Hoover K., Felton G.W. Herbivore-induced defenses in tomato plants enhance the lethality of the entomopathogenic bacterium, Bacillus thuringiensis var. kurstaki. Journal of Chemical Ecology. 2018; 44(10):947—956. Available from: doi: 10.1007/s10886-018-0987-4. 
[34] Babu A.N., Jogaiah S., Ito S.I., Nagaraj A.K., Tran L.S.P. Improvement of growth, fruit weight and early blight disease protection of tomato plants by rhizosphere bacteria is correlated with their beneficial traits and induced biosynthesis of antioxidant peroxidase and polyphenol oxidase. Plant Science. 2015; 231:62—73. Available from: doi: 10.1016/j.plantsci.2014.11.006.

\title{
INFORMATION ABOUT AUTHORS
}

Niloufar Mahmoudi - Department of AgroBiotechnology, Agrarian and Technological Institute, RUDN University, Moscow, Russian Federation; e-mail: niloofarmahmoodi@ymail.com

\section{For citation:}

Mahmoudi N. Study of the activity of peroxidase and polyphenol oxidase enzymes in cucumber infected with the nematode generating Meloidogyne javanica root node by the beta-aminobutyric acid stimulant. RUDN Journal of Agronomy and Animal Industries, 2019, 14 (1), 7-17. doi: 10.22363/2312-797X-2019-14-1-7-17.

\section{ВЛИЯНИЕ БЕТА-АМИНОМАСЛЯНОЙ КИСЛОТЫ НА АКТИВНОСТЬ ПЕРОКСИДАЗЫ И ПОЛИФЕНОЛ-ОКСИДАЗЫ У РАСТЕНИЙ ОГУРЦА, ПОРАЖЕННЫХ НЕМАТОДОЙ MELOIDOGYNE JAVANICA}

\author{
Niloufar Mahmoudi \\ Российский университет дружбы народов \\ 117198, Москва, ул. Миклухо-Маклая, д. 6
}

\begin{abstract}
Аннотация. Бета-аминомасляная кислота вводится в качестве индуктора устойчивости растений к патогенам растений. В данной работе была исследована индукция некоторых защитных соединений, в том числе ферментов пероксидазы и полифенолоксидазы этим соединением, против нематоды Meloidogyne javanica, продуцирующей узел корневища, в огурце. Результаты показали, что инокуляция корней зараженного огурца нематодой из корневых узлов с химическим составом БАМК с первого дня после инокуляции нематодой увеличивала активность фермента пероксидазы и достигала своего максимума на четвертый день этой активности. Индукция активности фермента полифенолоксидазы показала постепенное увеличение со значительной разницей по сравнению с контрольными и здоровыми растениями и достигла максимума на четвертый день. Электрофорез пероксидазных изозимов показал, что изоферментные пероксидазные формы в корнях огурца, индуцированные БАМК, гораздо более эффективны, чем индуцируемые патогеном изозимы. У растений, обработанных нематодой плюс БАМК, два изофермента имеют $\mathrm{Rf}=00,31$ и $\mathrm{Rf}=34 / 0$, которые являются более сильными, чем контроль (инокулированные нематодой).
\end{abstract}

Ключевые слова: индукция резистентности, корневая галловая нематода, бета-амино-масляная кислота, пероксидаза, полифенолоксидаза 